\title{
THE ANALYSIS OF THE EPIC POEM OF THE KOSOVO CYCLE CAR LAZAR I CARICA MILICA AND ITS TRANSLATION INTO ENGLISH
}

\begin{abstract}
In the translation of texts, it is generally acknowledged that the meaning of certain language units can never be entirely transferred from one language to another, and that the translation process does not solely include the text. Modern approaches to translation theory concentrate far more on the contextual aspect of translation. They view language as part of the expression of a certain culture and society, as a code which encompasses and transfers cultural norms, customs, cultural values and world views. However, in the translation of Serbian texts, epic ballads have presented the biggest challenge due to the fact that their basic characteristic is not the meaning, but the form, which is representative of the Serbian tradition. This paper will be based on an analysis of the Serbian epic poem of the Kosovo cycle Car Lazar $i$ carica Milica and its translations into English. Special attention will be paid to the ways in which the basic characteristics of Serbian epic poetry, such as meter and epic formula, are transferred to the English language. We will use three translations of this poem into English: Tsar Lazar and Tsaritsa Militsa (Of the Battle of Kosovo), a translation by Geoffrey Locke, Tsar Lazar and Tsaritsa Militsa, a translation by George R. Noyes and Leonard Bacon, and The Battle of Kossovo, a translation by Owen Meredith.
\end{abstract}

Key words: translation, epic poems, metrics, form

\section{Introduction}

Serbian epic poems represent an integral part of Serbian culture. Folk poets did not only sing about famous battles and events from the past, but also figures and events of their own time. Even though epic poems had long been perceived as "elementary pathetic, monotone and prosaic verses," their analysis shows that they were a form of cultivated artistic expression, framed by a highly disciplined stylistic convention.

For the purpose of proving the oral origin and style of Homer's epics, a theory was created based on the work of Milman Parry and Albert Lord, resulting in the creation of the Parry-Lord definition of the epic formula: "By formula, I mean a set

\footnotetext{
PhD candidate, University of Belgrade, Faculty of Philology, Studentski trg 3, 11000 Belgrade, Serbia; e-mail: draganajevtic88@gmail.com
} 
of words used regularly under the same metric conditions to express a given basic idea. This is Parry's definition. By using "formulaic expression," I signify a verse or a semi-verse constructed following the pattern of formulas. As for "topic," I regard it as repeated events and descriptive points in poems" (Lord 1990: 21). Detelić (1996: 8) stresses that this "great American endeavor ... left no noticeable mark when it came to studying Serbian decasyllable epic poetry". Furthermore, she says that, if the ParryLord theory can provide any basis whatsoever for the research of South Slavic epics, then it is in extending the notion of one-verse formulas, which is a metric milieu, to the syntactic milieu, a sentence, which most often crosses the borders of a single verse. According to her, this syntactic function of the formula was created as a response to the lack of transparency of the sacral milieu in the deepest layers of South Slavic epics.

When translating epic poems, in order not to simply transfer meaning, but also the culture of a people, their tradition and the essence of language, translators encountered various obstacles, such as metrics and established formulas, which adorn the Serbian oral tradition. Omitting them would take the readers away from the essence of the poem. There have been quite a few attempts to translate Serbian epic poems into English - some more successful, some less. In fact, we cannot even talk about the success of the translations here; but, rather, about the translation techniques that the translators used and the degree of adherence to the original text and its formula, which proved to be the most difficult challenge.

This paper will analyze the Serbian epic poem of the Kosovo cycle Car Lazar $i$ carica Milica in the translations by Owen Meredith, Geoffrey Locke, and the joint translation by George R. Noyes and Leonard Bacon into English. We will analyze the translations from the perspective of some of the basic qualities of epic poetry: metrics and the epic formula.

\section{Metrics}

The type of verse used in Serbian folk poetry is, of course, a decasyllable - a verse of ten syllables with a caesura before the fifth syllable. The word boundary before the fifth syllable of the verse is obligatory. According to Jakobson (1966: 149), this is an expression of the general tendency to establish the boundaries of the words before odd syllables and to single out two-syllable wholes. At least one of the boundaries of a lexical chunk has to be placed before an odd syllable, which means that it must match the boundary of the verse. Lexical chunks with an even number of syllables start with an odd syllable, while monosyllabic lexical units are placed on odd syllables. This is why word boundaries cannot appear before the fourth or tenth syllable. Jakobson (1966: 150) further states that these laws on monosyllabic lexical wholes demonstrate 
the trochaic tendency of the decasyllable, which means alternating rising and falling accents: this fall cannot be placed on a monosyllabic lexical chunk:

1) Car-Lazare, srpska kruno zlatna,

Ti polaziš sjutra u Kosovo,

S' sobom vodiš sluge i vojvode,

A kod dvora nikoga ne ostavljaš,

Care Lazo, od muškijeh glava,

Da ti može knjigu odnijeti

U Kosovo i natrag vratiti;

Devet braće, devet Jugovića:

Ostavi mi brata bar jednoga,

Jednog brata sestri od zakletve.

All these "rules" presented a great problem to translators in their attempts to transfer Serbian decasyllable verse into English. Such metrics is not natural in the English language, not just because of its relatively fixed word order in the sentence, but also because of a completely different system of accentuation. In an attempt to transfer the Serbian metric system as best they could, they sacrificed other things, such as epic formulas. Each of our three selected translations, however, uses a different type of verse.

Let's start with Geoffrey Locke's translation. In the foreword to his translation (2011: 30), Locke himself says that the stressed/accentuated syllable in the English language is so important that, if moved to a different syllable in a word, the entire word will be completely incomprehensible or it will change its meaning. Let's look at an example from his translation of the poem Car Lazar i carica Milica:

2) Tsar Lazar, Golden Crown of Serbia!

Tomorrow you will go to Kosovo,

Leading the kings and all the Serbian host -

Leaving us womenfolk alone, good Tsar,

With no stout King to act as messenger,

To carry news to you at Kosovo,

And bring us letters back to tell of you.

As we can see, he did not even try to adapt the verse of the translation to the original. Instead, he is using the traditional pentameter of English traditional free verse (blank verse), which is, in his opinion, the closest counterpart in English and which for the majority of the translation is Iambic, but not completely. However, he adhered to the strictly decasyllabic verse for the purpose of, as he says, paying homage to the 
numerous Serbian folk poets who strived for years to shape their poetic inspiration into the rigid decasyllabic mold (2011: 31 ).

Let's look at the verses from the same poem in the translation by Noyes and Bacon:

3) O Servia's king and crown,

Tomorrow unto Kosovo the army goeth down,

Thy voyvodas and captains. No man thou leavest at home

With a letter to go to Kosovo and hither to come.

Thou leadest my nine brethren, Yug Bogdan's children nine -

Leave me one brother of them all to cheer this heart of mine.

These two translators also believed that attempts to transfer the original metrics would be in vain, so they also resorted to a type of "domestic" versification - the metrics that William Morris used in his epic poem The Story of Sigurd the Volsung and the Fall of the Niblungs, i.e., a verse of thirteen syllables. As we can see, there is a slight departure, i.e., a mixture of thirteen-syllable and fourteen-syllable verses. An $\mathrm{AABB}$ rhyme scheme is used throughout the poem, which was never a characteristic of Serbian epic poetry.

4) Lord Lazarus, $\mathrm{O}$ golden crown

Of Servia, and sweetheart my own!

Tomorrow morn to Kosovo

With thee to the battle go

Servitors and Voïvodes.

I alone, in these abodes,

Vacant of thy voice, remain;

Hearing, haply, on the wind,

Murmurs of the battle plain;

Heavy of heart, and sad of mind,

Silent of sorrow, alone with pain,

O think on this, my life, my lord,

Never a soul to carry a word.

To Kossovo, from me to thee,

To Krouchevatch from thee to me;

Wherefore, lord, of my brothers nine,

The sons of Youg, our father old,

(Golden stars in a crown of gold!) 
Example 4 is from the translation by Owen Meredith, who clearly diverges most from the original in terms of metrics. The translator uses the catalectic trochaic tetrameter, characteristic of Shakespeare, which gives the translation a certain mystical quality. He also uses the AABB rhyme scheme, as well as an ABAB rhyme scheme.

None of the three translations adhered to the original metrics because it was presumed that, in doing so, the translation would lose something on a different plane as the metrics of the Serbian epic decasyllable is closely intertwined with the lexis and the flexibility of the Serbian language when it comes to the sentence word order.

\section{Epic formulas}

According to Detelić (1992: 274), nowadays, formula is understood, among other things, as: "1) the regular placing of the same word in a specific position in the verse; 2) the reiteration of expressions consisting of two or more words; 3 ) the reiteration of syntactic structures, i.e., patterns; 4) the reiteration of entire verses; 5) the reiteration of several verses; 6 ) the reiteration of equal semantic cores in various forms of expression; 7) the reiteration of motifs; 8) the reiteration of sets of motifs." And, according to her, even from this incomplete overview, it can be seen that a formula can be found on every structural plane of the text. Taken to its extreme, the definition of the formula would cancel itself out. Therefore, Detelić notes the need for a term to refer to "the important quality of oral literature to create formulas so that it can use them as a basic means of expression and artistic shaping at different levels of the poetic text, including its expressive and content forms," a notion known in literature as formulativity (1992: 275).

She also mentions that there is a hierarchy among formulas, that the oldest ones are "true formulas," which are also the most valuable ones. These are followed by "rudimentary formulas" - bijelo grlo, bijeli dan, crna zemlja, etc., and then, according to the Parry-Lord definition, by the "formulas in the making," i.e., moveable and changeable strings of words that can easily fit asymmetric oral epic decasyllable verse (Detelić 1992: 123).

The "formula in the making" is a dynamic poetic means directly tied to the formulative nature of epic language, conditioned by the metrical characteristics of the epic decasyllable. It stands apart from other similar verses due to its caesura after the fourth syllable and the quantitative close, which was first brought to attention by Jakobson (1966: 154), defining it as the rule of trochaic falling intonation - seeing as how the trochee does not tolerate stress on the last syllable, the penultimate has to be long or stressed. In this context, having a "stock" of pre-formed strings of words which fit in any of these two segments of asymmetrical verse proves significant, as in the pair zora bela (4 syllables) and zorica bijela (6 syllables). 
Why is recognizing epic formulas important when translating epic poems? The very fact that, in decasyllabic poetry, there is a break, a caesura, after the fourth syllable, tells us that only specific language strings/sequences can find themselves in certain positions. This does not prove to be a limitation of the Serbian decasyllable; rather, it shows the skill and linguistic ingenuity that the Serbian folk poets had to use in order to tell a different tale every time while using similar formulas (used forms).

In this paper, we will deal with the types of epic formulas that are used in the poem Car Lazar i carica Milica, their form and the way these formulas were transferred into English. As we can see, the fundamental quality of epic formulas is repetition/ reiteration. In order to adhere to the original text consistently, the translation needs to include the repetition of certain formulas. Also, it is important that the translator is familiar with all the types of formula (the aforementioned "true" and "rudimentary" formulas and "formulas in the making"), i.e., that the translator is familiar with the tradition of Serbian oral poetry, so they do not change or omit such formulas (whether they appear once or several times in a specific text) because then the translated epic poem will lose its basic qualities.

In the translations of the poem Car Lazar i carica Milica, we did not deal with the classification of the formulas according to the Parry-Lord model. Instead, we divided them into two groups according to form - syntagmatic formulas ("rudimentary formulas" according to the Parry-Lord model) and higher syntactic wholes/units.

\subsection{Syntagmatic formulas}

Noun phrases that are characteristic of epic poems follow the pattern modifier + noun (however, often, due to the fact that in Serbian the word order in the sentence can be altered without the structure's grammar suffering, we encounter the pattern noun + modifier, which corresponds to the intonation of the epic decasyllable) and noun + postmodifier (i.e., case attribute + noun). In the poem Car Lazar i carica Milica, there are 40 different noun phrases that follow these patterns ${ }^{1}$. What is interesting is that 38 of these 40 phrases can be found in the final position, i.e. the position after the caesura. (The exceptions were the phrase (za) krst časni, which took the initial position, and the phrase bijel dan, which took the medial position.) They either had 6 syllables or formed 6 syllables with an adequate preposition.

\footnotetext{
${ }^{1}$ This does not include those phrases that are repeated, such as vojska na alaje - twice, bijela kula - three times, and others. They will be included in the analysis because it is important to see how consistent the translators were in their translations.
} 


\begin{tabular}{|c|c|c|c|c|}
\hline & $\frac{\text { Noun phrases }}{\text { (original version) }}$ & $\begin{array}{c}\text { Geoffrey Locke's } \\
\text { translation }\end{array}$ & $\begin{array}{l}\text { George R. } \\
\text { Noyes and } \\
\text { Leonard Bacon's } \\
\text { translation }\end{array}$ & $\begin{array}{c}\text { Owen Meredith's } \\
\text { translation }\end{array}$ \\
\hline 1 & $\begin{array}{l}\text { srpska kruno zlatna } \\
\text { (F) }\end{array}$ & $\begin{array}{l}\text { Golden Crown of } \\
\text { Serbia (F) }\end{array}$ & $\begin{array}{l}\text { O Servia's king and } \\
\text { crown (I) }\end{array}$ & $\begin{array}{l}\text { O golden crown of } \\
\text { Servia }(F / I)\end{array}$ \\
\hline 2 & $\begin{array}{l}\text { od muškijeh glava } \\
\text { F) }\end{array}$ & / & $\operatorname{man}(\mathrm{M})$ & a soul $(\mathrm{M})$ \\
\hline 3 & $\begin{array}{l}\text { devet mile braće } \\
\text { (F) }\end{array}$ & those famous nine (I) & nine brethren $(\mathrm{M})$ & my brothers nine $(\mathrm{F})$ \\
\hline 4 & $\begin{array}{l}\text { sestra od zakletve } \\
\text { (F) }\end{array}$ & / & / & / \\
\hline 5 & $\begin{array}{l}\text { (u) bijelu dvoru } \\
\text { (2) (F) }\end{array}$ & $\begin{array}{l}\text { - in this fair hall (F) } \\
\text { - (In Krushevats) (F) }\end{array}$ & $\begin{array}{l}\text { - in the palace (I) } \\
-/\end{array}$ & $\begin{array}{l}\text { - (in our) white } \\
\text { palace (I) } \\
-/\end{array}$ \\
\hline 6 & bijel dan (M) & $\begin{array}{l}\text { dawn (I)(When dawn } \\
\text { brings forth the day) }\end{array}$ & day (M) & watery dawn (I) \\
\hline 7 & $\begin{array}{l}\text { - gradu na kapiju } \\
\text { (F) } \\
\text { - gradu kod } \\
\text { kapije }(F)\end{array}$ & $\begin{array}{l}\text { - the city gates }(\mathrm{M}) \\
\text { - the gates }(\mathrm{M})\end{array}$ & $\begin{array}{l}\text { - the gates of the city } \\
\text { (M) } \\
\text { - the gateway (M) }\end{array}$ & $\begin{array}{l}\text { - the city walls (M) } \\
\text { - the shadowy city } \\
\text { walls (F) }\end{array}$ \\
\hline 8 & $\begin{array}{l}\text { - krstaša barjaka }(F) \\
\text { - Krstaš ga je barjak } \\
\text { - Krstaš barjak } \\
(\text { dao })(F)\end{array}$ & $\begin{array}{l}\text { - the sacred flag of } \\
\text { Christendom }(\mathrm{F}) \\
\text {-the sacred Christian } \\
\text { flag }(\mathrm{F}) \\
\text { - the sacred flag }(\mathrm{M})\end{array}$ & $\begin{array}{l}\text { - standard with the } \\
\text { great cross glorified } \\
\text { (F) } \\
\text { - standard (I) } \\
\text { - the flag with the } \\
\text { great cross glorified } \\
\text { (F) } \\
\text { - (the golden banner) }\end{array}$ & $\begin{array}{l}\text { - the standard of the } \\
\text { Cross (F) } \\
\text { - the standard of the } \\
\text { Cross (F) } \\
\text { - the Holy Cross (I) }\end{array}$ \\
\hline 9 & $\begin{array}{l}\text { vojska na alaje (F) } \\
\text { (2) }\end{array}$ & $\begin{array}{l}\text { - battalions under } \\
\text { arms }(\mathrm{F}) \\
\text { - the Serbian legions } \\
\text { under arms (I) }\end{array}$ & $\begin{array}{l}\text { - unto the muster the } \\
\text { hosts }(\mathrm{M}) \\
\text { - unto the muster the } \\
\text { host }(\mathrm{M})\end{array}$ & $\begin{array}{l}\text { - the army }(F) \\
\text { - the army (F) }\end{array}$ \\
\hline 10 & $\begin{array}{l}\text { bojnim kopljima } \\
\text { (F) }\end{array}$ & (with his) lance (F) & the spears (I) & (with) curtle axe \\
\hline 11 & (u) čistom zlatu (F) & (mailed) in gold (F) & $\begin{array}{l}\text { (with) shining } \\
\text { goldwork glowed (F) }\end{array}$ & all blazing gold (I) \\
\hline 12 & $\begin{array}{l}\text { do konja alata (2) } \\
\text { (F) }\end{array}$ & horse $(\mathrm{M})$ & $\begin{array}{l}\text { - steed (I) } \\
\text { - steed (I) }\end{array}$ & courser \\
\hline
\end{tabular}


Dragana Janković

\begin{tabular}{|c|c|c|c|c|}
\hline 13 & od zlata jabuka (F) & with golden orbs $(\mathrm{F})$ & an apple of gold (F) & $\begin{array}{l}\text { an apple wrought of } \\
\text { purest gold }\end{array}$ \\
\hline 14 & od zlata krstovi (F) & a gold cross $(\mathrm{F})$ & gilded crosses (M) & $\begin{array}{l}\text { the great gold cross } \\
\text { (M) }\end{array}$ \\
\hline 15 & zlatne kite $(\mathrm{M})$ & $\begin{array}{l}\text { flowers of pure } \\
\text { gold }(\mathrm{F})\end{array}$ & tassels (M) & $\begin{array}{l}\text { great golden acorns } \\
\text { (I) }\end{array}$ \\
\hline 16 & $\begin{array}{l}\text { brata od zakletve } \\
\text { (2) (F) }\end{array}$ & $\begin{array}{l}\text { - brother still to } \\
\text { hold }(F)\end{array}$ & $\begin{array}{l}\text { - that I may have } \\
\text { thee still }(\mathrm{F}) \\
\text { - that I may have } \\
\text { thee still }(\mathrm{F})\end{array}$ & $\begin{array}{l}\text { - (I may have one) } \\
\text { to swear by }(\mathrm{F} / \mathrm{I}) \\
\text { - to swear by }(\mathrm{F} / \mathrm{I})\end{array}$ \\
\hline 17 & $\begin{array}{l}\text { (na) bijelu kulu } \\
\text { (4)F }\end{array}$ & $\begin{array}{l}\text { - fair hall (F) } \\
\text { - fair hall (F) } \\
\text { - (to) the very } \\
\text { palace of the Tsar } \\
\text { (F) } \\
\text { - hall (F) }\end{array}$ & $\begin{array}{l}\text { / } \\
\text { - the hall (M) } \\
\text { - the white palace } \\
\text { (M) } \\
\text { - the wall (F) }\end{array}$ & $\begin{array}{l}\text { - (to thy) white } \\
\text { tower (I) } \\
\text { - (to thy) white } \\
\text { tower (I) } \\
\text { - the hall (F) }\end{array}$ \\
\hline 18 & $\begin{array}{l}\text { (za) krst časni } \\
\text { (2) (I) }\end{array}$ & $\begin{array}{l}\text { - for Jesus' sake } \\
\text { (F) } \\
\text { - for Jesus' sake } \\
\text { (F) }\end{array}$ & $\begin{array}{l}\text { - for Christ his } \\
\text { Cross (and faith) } \\
\text { (M) } \\
\text { - the Cross (M) }\end{array}$ & $\begin{array}{l}\text { - for Holy Rood } \\
\text { (F) } \\
\text { - for Holy Rood } \\
\text { (F) }\end{array}$ \\
\hline 19 & $\begin{array}{l}\text { suvijem zlatom } \\
\text { (F) }\end{array}$ & $\begin{array}{l}\text { (in cloth of) gold } \\
\text { (F) }\end{array}$ & $\begin{array}{l}\text { (of) shining gold } \\
\text { (M }\end{array}$ & $\begin{array}{l}\text { all trapt and housed } \\
\text { with gold (I) }\end{array}$ \\
\hline 20 & Kosovo ravno $(\mathrm{F})$ & $\begin{array}{l}\text { the level plain of } \\
\text { Kosovo }(F)\end{array}$ & on level Kosovo F & at Kossovo (F) \\
\hline 21 & $\begin{array}{l}\text { (na) kamen } \\
\text { studeni }(F)\end{array}$ & $\begin{array}{l}\text { on the cold stones } \\
\text { (M) }\end{array}$ & stone $(\mathrm{M})$ & cold curb-stone $(\mathrm{F})$ \\
\hline 22 & $\begin{array}{l}\text { slavnoga Lazara } \\
(\mathrm{F})\end{array}$ & The Tsar & king Lazar (I) & the Tsar \\
\hline 23 & $\begin{array}{l}\text { moja vjerna slugo } \\
\text { (F) }\end{array}$ & $\begin{array}{l}\text { my trusty servant } \\
\text { (I) }\end{array}$ & $\begin{array}{l}\text { my good } \\
\text { henchman }(\mathrm{M})\end{array}$ & $\begin{array}{l}\text { my faithful friend } \\
\text { (F) }\end{array}$ \\
\hline 24 & $\begin{array}{l}\text { Od konja labuda } \\
\text { (3) (F) }\end{array}$ & $\begin{array}{l}\text { / } \\
\text { - his battle horse } \\
\text { (I) - his horse (I) }\end{array}$ & $\begin{array}{l}1 \\
1 \\
1\end{array}$ & $\begin{array}{l}\text { - milk-white horse } \\
\text { (M) } \\
\text { - milk-white steed } \\
\text { (F) } \\
\text { - milk-white war- } \\
\text { horse (M) }\end{array}$ \\
\hline 25 & $\begin{array}{l}\text { (niz) bijelo lice } \\
\text { (F) }\end{array}$ & his cheeks $(F)$ & / & / \\
\hline
\end{tabular}


THE ANALYSIS OF THE EPIC POEM OF THE KOSOVO CYCLE CAR LAZAR I CARICA MILICA

\begin{tabular}{|c|c|c|c|c|}
\hline 26 & $\begin{array}{l}\text { (na) bijele ruke } \\
\text { (F) }\end{array}$ & soft hand (F) & $\operatorname{arms}(\mathrm{M})$ & (in) thy true arms \\
\hline 27 & $\begin{array}{l}\text { (na) tananu kulu } \\
\text { (F) }\end{array}$ & $\begin{array}{l}\text { - a peaceful place } \\
\text { (M) } \\
\text { - a peaceful room } \\
\text { (M) }\end{array}$ & $\begin{array}{l}\text { - slender tower }(F) \\
\text { - slender tower }(F)\end{array}$ & $\begin{array}{l}\text { - to her tall tower } \\
\text { (F) } \\
\text { - to her tall tower } \\
\text { (F) }\end{array}$ \\
\hline 28 & $\begin{array}{l}\text { dva vrana } \\
\text { gavrana (4) (F) }\end{array}$ & $\begin{array}{l}\text { ravens, as dark as } \\
\text { night }(\mathrm{F}) \\
\text { - ravens, dark as } \\
\text { night }(\mathrm{F}) \\
\text { - the two black } \\
\text { ravens (F) }\end{array}$ & $\begin{array}{l}\text { - a pair of great } \\
\text { black ravens (I) } \\
\text { - those two ravens } \\
\text { (I) } \\
\text { - black ravens (M) } \\
\text { - black ravens (M) }\end{array}$ & $\begin{array}{l}\text { - two ravens (I) } \\
\text { - the two black } \\
\text { birds (I) } \\
\text { - black ravens (F) } \\
\text { two black fowls (I) }\end{array}$ \\
\hline 29 & $\begin{array}{l}\text { (Od) Kosova } \\
\text { polja širokoga } \\
\text { (ceo red) }\end{array}$ & / & $\begin{array}{l}\text { the broad } \\
\text { battlefield (F) }\end{array}$ & (from) Kossovo (I) \\
\hline 30 & $\begin{array}{l}\text { dvije silne vojske } \\
\text { (2) (F) }\end{array}$ & $\begin{array}{l}\text { - two mighty } \\
\text { armies (F) } \\
\text { - two great armies } \\
\text { (M) }\end{array}$ & $\begin{array}{l}\text { - the armies }(\mathrm{F}) \\
\text { - two hosts (I) }\end{array}$ & $\begin{array}{l}\text { - two armies }(\mathrm{F}) \\
\text { - two great armies } \\
\text { (F) }\end{array}$ \\
\hline 31 & $\begin{array}{l}\text { (sa) konja viteza } \\
\text { (F) }\end{array}$ & l & $\begin{array}{l}\text { the great steed of } \\
\text { war }(F)\end{array}$ & horse (M) \\
\hline 32 & $\begin{array}{l}\text { studenom } \\
\text { vodicom }(2)(\mathrm{F})\end{array}$ & $\begin{array}{l}\text { - cold water }(F) \\
\text { - cold water }(F)\end{array}$ & $\begin{array}{l}\text { - cool water }(M) \\
\text { - white water }(M)\end{array}$ & $\begin{array}{l}\text { - water cold }(F) \\
\text { - water cold }(F)\end{array}$ \\
\hline 33 & $\begin{array}{l}\text { crvenijem vinom } \\
\text { (2) }(\mathrm{F})\end{array}$ & $\begin{array}{l}\text { - red wine }(M) \\
\text { - red wine }(M)\end{array}$ & $\begin{array}{l}\text { - ruddy wine }(\mathrm{M}) \\
\text { - red wine }(\mathrm{F})\end{array}$ & $\begin{array}{l}\text { - (with) rosy wine } \\
\text { (F) } \\
\text { - (with) rosy wine } \\
\text { (F) }\end{array}$ \\
\hline 34 & $\begin{array}{l}\text { - slavni kneže } \\
\text { Lazo }(\mathrm{F}) \\
\text { - slavni knez } \\
\text { Lazare }(\mathrm{F}) \\
\text { - slavnog knez- } \\
\text { Lazara }(\mathrm{F})\end{array}$ & $\begin{array}{l}\text { - Tsar Lazar the } \\
\text { Glorious (F) } \\
\text { - Tsar Lazar the } \\
\text { Glorious (F) } \\
\text { - glorious Tsar } \\
\text { Lazar (F) }\end{array}$ & $\begin{array}{l}\text { - the Tsar Lazar (F) } \\
\text { - Lazar the Tsar } \\
\text { glorious (I) } \\
\text { - good Tsar Lazar } \\
\text { (I) }\end{array}$ & $\begin{array}{l}\text { - the great Lazar } \\
\text { (F) } \\
\text { - Glorious Prince } \\
\text { Lazar(F) } \\
\text { - The Tzar (F) }\end{array}$ \\
\hline 35 & $\begin{array}{l}\text { stari Jug Bogdane } \\
\text { (2) (F) }\end{array}$ & $\begin{array}{l}\text { - venerable Yug } \\
\text { Bogdan (F) } \\
\text { - old Yug Bogdan } \\
\text { (I) }\end{array}$ & - my father (I) & $\begin{array}{l}\text { - my father, Youg } \\
\text { Bogdan (F) } \\
\text { - gray-hair'd Youg } \\
\text { Bogdan (F) }\end{array}$ \\
\hline
\end{tabular}


Dragana Janković

\begin{tabular}{|c|l|l|l|l|}
\hline 36 & $\begin{array}{l}\text { krvca do koljena } \\
(\mathrm{F})\end{array}$ & $\begin{array}{l}\text { to his knees in } \\
\text { blood (F) }\end{array}$ & $\begin{array}{l}\text { the blood flowed } \\
\text { up to the knee (M) }\end{array}$ & $/$ \\
\hline 37 & $\begin{array}{l}\text { (kod) vode } \\
\text { studene (F) }\end{array}$ & icy stream (F) & cool waters (F) & $/$ \\
\hline 38 & $\begin{array}{l}\text { (spomen) rodu } \\
\text { srpskom (F) }\end{array}$ & Serbian folk (F) & the Serbs (F) & Servia (M) \\
\hline 39 & $\begin{array}{l}\text { (za) prokletog } \\
\text { Vuka }\end{array}$ & $\begin{array}{l}\text { (of) Vuk Brankovic } \\
(\mathrm{F})\end{array}$ & the cursed Vuk (M) & (of) Vouk (I) \\
\hline 40 & $\begin{array}{l}\text { ljutog oklopnika } \\
(\mathrm{F})\end{array}$ & horsemen (M) & $/$ & $/$ \\
\hline
\end{tabular}

*(I - initial position, $\mathrm{M}$ - medial position, $\mathrm{F}$ - final position; (2) - it is repeated twice in the poem, (3) - three times, (4) - four times)

To consider a formula consistently translated, it needs to be used in the selected form every time it is repeated. We say selected because, when it comes to language structure, it is almost impossible to harmonize different languages, especially those that belong to different language groups. The English language has a fixed word order, which can rarely vary, while this is not the case with Serbian. Therefore, if adhering to repetitiveness is the goal here, it would be ideal if a corresponding expression could be found, which could "in general" transfer the meaning and the form itself.

However, as can be seen from the table, even though there are certain matches, the translators were not consistent. Let's demonstrate this with some of the examples. One of the phrases that was repeated most was krstaš barjak (we find it in the text in the forms krstaša barjaka, krstaš ga je barjak and krstaš barjak). In Geoffrey Locke's translation, we find it as the sacred flag of Christendom, the sacred Christian flag and the sacred flag. As you can see, this phrase was translated in a different way every time, even though their positions in the verse match in the first and the third form. The second form, the sacred Christian flag, does not match the initial position of the original krstaš ga je barjak. The same is true for Noyes and Bacon's translation of the same phrase. In their version, we have the variants standard with the great cross glorified, standard and the flag with the great cross glorified, while in Meredith's version we find the standard of the Cross (twice) and the Holy Cross. The translation of this phrase proves the proves the idea that the English language lacks flexibility when it comes to word order. While in Serbian, the attribute and the noun that form the phrase can be separated by a word (as in the case krstaš ga je barjak), this is not the case in English. 
The examples bijela kula, bijeli dvor, bijelo lice, bijele ruke and bijeli dan (white tower, white palace, white face, white hands/arms and white day) are also interesting. As we know, white has great significance in Serbian epic tradition. In her paper, in which she deals with the adjectives junački and beli in Serbian epic poetry, Mirjana Detelić clarifies the frequency of these adjectives (1995: 129-130). Namely, belo, linked with a hand, legs or face, signifies the noble origin of the character, his or her easy life without any troubles or strenuous activity. Originally, it was linked with the aristocracy, kings, royals, dukes and ladies, but, over time, once the old nobility had disappeared from the historical scene, it slid imperceptibly to the lower classes. Kula (tower) and grad (city), she claims, are mostly tied to the adjective beli (white). According to Detelić, this is because, aside from its military function, the city was first and foremost an administrative center, the image of power and security, and, in the case of a big city or a capital, also a symbol of divine authority on earth. This earthly power was mostly tied to religious power, so rulers were both a temporal and sacral institution. In this way, they laid claim to the privilege of being designated as white because, in the system of Indo-European societies, it was the color of high priests or kings. Therefore, the concept of the "white city", especially when connected to a holy ruler, is shown to be one of the oldest categories of not only Pan-Slavic, but also Pan-European significance, an important element of current European cultural heritage and history. Even though beli + grad (white + city) exists in the tradition of all Slavic peoples as an extremely frequent epic formula, beli grad occurs solely in SerbianCroatian epics. From this perspective, we can conclude that it is extremely important to keep the adjective white in the translation.

However, by analyzing the table, we can conclude that translators did not adhere to such logic and translated phrases containing the adjective beli (white) arbitrarily. Therefore, bijeli dvor (white palace), which appears twice in the text, was translated was translated once as fair hall and once as Krushevats by Geoffrey Locke, once as palace by Noyes and Bacon, without any adjective, while it was not even translated the second time, and, lastly, as white palace by Owen Meredith, who also did not translate it the second time. Bijelo lice (white face) was also not translated, except in Locke's translation, when he only used cheeks. The phrase bijela kula (white tower) was mentioned four times in the original. Locke translated it twice as fair hall, once as palace, and once as just hall. On the other hand, in Noyes and Bacon's translation, we have the hall, the white palace and the wall, while in Meredith's, we find white tower twice and hall once. This is interesting because it can confirm Detelic's idea that beli + grad (white + city) is an important part of European historical heritage and history. Therefore, it might be more natural for translators to translate such phrases consistently because it is a part of their cultural heritage as well. 
The translation of the phrase dva vrana gavrana can also serve as an example of the notion of Pan-European cultural heritage. Since we are discussing translations into English, it should be mentioned that in Northern European countries, birds like ravens, vultures and other birds that feed on the bodies of the dead are often presented as symbols of war, death and misfortune, which is also the case in Serbian tradition and mythology. The appearance of a raven in a Serbian epic poem usually symbolizes death and bad news, e.g., dva vrana gavrana (two black ravens) are usually the bearers of bad news, usually the news of someone's death. Therefore, it is not surprising that this phrase, in addition to the phrase beli grad, is one of the phrases that were translated consistently. Namely, the translations almost always stress the black color that goes with the raven, as a symbol of death and bad news (Locke: ravens, as dark as night, ravens, dark as night, the two black ravens; Noyes and Bacon: a pair of two black ravens, those two ravens, black ravens (twice); Meredith: two ravens, the two black ravens, black ravens, two black fowls). It would be interesting to carry out an analysis on a slightly larger corpus of translations to see which epic formulas are actually translated most consistently, which could serve as proof of the connection between cultures and the existence of universal categories. We can find confirmation of such a claim in the translation of the phrases verni sluga, studena voda, and crveno vino (see the table).

\subsection{Translation of formulas as larger syntactic wholes}

Detelić (1995: 325-326) stresses that the basic principle of every speech sequence, even oral literary text, is segmentation. However, unlike a common speech sequence, the oral literary text is an "artificial, derived" system with absolute borders where metric principles have to be taken into consideration. Therefore, according to Detelić, the epic poem has several internal borders occurring at the points of contact between successive segments, called constructive borders, which are marked by epic formulas in the epic poem. The beginning and the end of the epic poem generally suffer the largest burden, which is why they are the most clichéd parts. Suvajdžić (2008: 148) states that "as a rule, a formula is not strictly tied to a certain text or even a certain subject of a poem; rather, it can, if necessary, if the same situation or the same detail of the action appears, be included in whichever text and used while creating new poems." In other words, we have larger syntactic units which can be used to start or finish a certain poem, to point to a change in place and time in terms of the action, i.e., to a change in scene, etc.

Such formulas serve to unburden the narration and divert attention away from less important parts of the text to what is at the center of the poem. However, such formulas can also be quite important because they can determine the direction of the 
text. For example, if the phrase dva vrana gavrana appears in the introduction, the poem will certainly continue in a negative way.

Some of them include initial formulas such as Mili bože čuda velikoga/Mili bože čuda golemoga/Vino pije kraljeviću Marko/Od kakoje svet postanuo, and final formulas like To je bilo kad je se činilo/Ni tu bio ni pravo kazao!/Da se priča i pripovjeda dok je sunca $i$ dok je mjeseca! Constructive formulas, i.e., internal formulas that cannot occur at the beginning or the end, exist to connect adjacent segments. They are open and can be found in various forms. In his work, Suvajdžić also lists many types of formulas, such as invocation formulas, communicative convention formulas (in which he includes formulas of speech, formulas of praising the hero, formulas of the fairy gloating, formulas of giving one's blessing or cursing, etc.), formulas of naming the hero, formulas of action, formulas of time (a long time ago or recently), formulas of Slavic antithesis (the Slavic antithesis of color/sound/symbol), formulas of dream, state, illness, formulas to signify processes in nature, and formulas of movement.

In this paper, we will only pay attention to those formulas that make up larger syntactic units and specifically only to those that are repeated, so we can analyze the consistency in translation and whether the translators themselves tried to sustain such formulas.

In the very beginning, when we first read the poem, we see that a formula appears which serves to separate events in a temporal manner:

5) a) Kad sjutra bjel dan osvane, which also appears in the forms:

b) Kad ujutru jutro osvanulo,

c) Kad je sjutra jutro osvanulo

In the translations, we can see that the translators did not adhere to this formula very closely (examples $6 \mathrm{a}, 6 \mathrm{~b}$ and $6 \mathrm{c}$ are from Geoffrey Locke's translation, $7 \mathrm{a}, 7 \mathrm{~b}$, and $7 \mathrm{c}$ from Noyes and Bacon's, and $8 \mathrm{a}, 8 \mathrm{~b}$ and $8 \mathrm{c}$ from Meredith's):

6) a) Tomorrow, then, when dawn brings forth the day

b) So when the gates were opened, with the dawn

c) At last the morrow's morn brought forth the day

Examples $6 \mathrm{a}$ and $6 \mathrm{c}$ have some similarities, like the expression brings forth the day, while example $6 \mathrm{~b}$ is not an adequate translation because the entire expression is reduced to the preposition construction with the dawn.

7) a) Lady, tomorrow, when day comes on

b) Now when the gates were opened, what time the morning shone

c) When rose up the white morning 
As we can see, there is no consistency in translation here.

8)
a) Tomorrow, when from her red bower
The watery dawn begins to break
b) Now, when the dawn from her red bower
Upclomb the chilly skies
c) All when the misty morn was low

Even in Owen Meredith's translation, we cannot find equivalents and consistency in translation. ${ }^{2}$

Another formula which is commonplace in all Serbian epic poems is krst časni krvcu proljevati, which is repeated twice in the text. We have already discussed the translation of the phrase krst časni in the table and now we will see how the translators transferred the entire formula.

Locke:

9) a) (Who dared) not shed his blood for Jesus' sake

b) I go, to shed my blood for Jesus' sake

Noyes and Bacon:

10) a) to perish for Christ his Cross and Faith on the field of Kosovo

b) I would ride to death for the Cross and the Faith on level Kosovo

Meredith:

11) a) Nor pour'd his blood for Holy Rood,

b) To pour my blood for Holy Rood

As we can see, Noyes and Bacon were the least consistent in their translation since their first and second translation of the formula differ significantly. On the other hand, Locke and Meredith were more or less consistent because they translated both krst časni and krvcu proljevati the same way. The only thing different from the original is the word order, which relates to the English language. Namely, the way syntactic units like the one in the original are switched (adverbial phrase of purpose + object

\footnotetext{
${ }^{2}$ Meredith translated the text quite freely. Aside from the basic plot, there are no other similarities to the original. The text is full of additional descriptions that paint a picture of the Victorian period, in which he wrote, and which were more characteristic of the lyric tradition than the epic one. So, even though in his translation he repeated most of the structures that are repeated in the original, he did so in a way that is not characteristic of epic poetry. To compare, in the original, the poem Car Lazar i carica Milica has 204 verses, while Owen Meredith's translation has 430 verses, which just shows how many verses he added.
} 
+ predicate) is not possible in English, as is shown in the translations. In all three translations, the predicate comes first.

Finally, there's the formula of giving one's blessing, which appears three times in the text:

12) a) Kaži njemu od mene blagoslov

b) I tebe je blagosov kazao

c) I tebe je blagoslov kazao

13) a) Tell him with my blessing he may give

b) But says that with his blessing, you may give

c) The Tsar has given you to me - he gives blessing - you must choose another squire (Locke)

14) a) Bless him! Let give the standard to whomsoever he will;

b) Thou shalt not go to Kosovo; he gives his blessing to thee;

c) Thou shalt not go to Kosovo; he gives his blessing to thee. (Noyes and Bacon)

In Locke's translation, we see that he tried to link the expression blagoslov kazati in examples $13 \mathrm{a}$ and $13 \mathrm{~b}$ by using the expression with my blessing. However, he did not do the same in example 13c, while Noyes and Bacon were more consistent, because examples $14 \mathrm{~b}$ and $14 \mathrm{c}$ are the same, which is the case in the original (examples $12 \mathrm{~b}$ and $12 \mathrm{c})$.

When analyzing the examples from Owen Meredith's work, we cannot speak about translation because he did truly diverge from the original to a great extent, but we can speak about reiteration of the formulas in the translation:

15) a) Greet him fair from his lord the king

b) He greets thee fair, and bids me say

c) He greets thee fair, and bids me say

Even though his translation differs from the original, Meredith tries to transfer the formulas, which are consistent through all three examples (15a, 15b, 15c).

\section{Conclusion}

In this paper, we have analyzed the ways in which the epic poem Car Lazar $i$ carica Milica has been translated, i.e., the extent to which translators were consistent in translating metrics and epic formulas. As far as metrics is concerned, none of the selected translators adhered to the original metrics. However, we have seen that Locke and Noyes and Bacon tried to use some sort of the metrics that appears in heroic 
poetry. Locke used the pentameter of English free verse, while Noyes and Bacon used the metrics of Morris' poetry. Meredith, on the other hand, did not try to transfer the "heroic" metrics; instead, he introduced lyric metric means in his translation, which are not characteristic of epic poetry.

When it comes to the formulas, we have seen that Serbian epic poetry is full of clichéd expressions that represent universal, and, at the same time, unique notions in Serbian culture and tradition, to which attention needs to be paid in analysis and translations. Considering the way that sentences are formed in English, it is not possible to expect 100-percent matches with the original. However, it is expected that, when translating such texts, translators be aware of the qualities of the original as the bearer of the culture and tradition of a people. In this paper, the focus was placed on formulas that are repeated in the text so we could draw conclusions regarding the consistency of the translators and see whether they treated such expressions as formulas, thus giving them the importance that they have in general analysis. From the table which includes formulas at the level of phrases, it can be seen that even though there are some matches when it comes to formulas at the level of phrases/syntagms, these are insufficient to be accepted as consistency, while there are more matches in the translation of those expressions that are repeated at the level of higher syntactic units.

\section{References}

Detelić, M. (1992). Mitski prostor i epika. (26 April 2015) $<$ http://www.mirjanadetelic.com/docs/Mitski\%20prostor\%20i\%20epika.pdf>.

Detelić, M. (1995). Ka poetici epske formule. (26 April 2015) <http://www. mirjanadetelic.com/docs/Ka\%20poetici\%20epske\%20formule.pdf>.

Detelić M. and M. Ilić (2006). Beli grad. (20 May 2015) <http://www.academia. edu/1466497/Beli_grad._Poreklo_epske_formule_i_slovenskog_toponima_ White_City._The_Origin_of_an_Epic_Formula_and_a_Slavic_Toponym $>$.

Detelić, M. (1996). Urok i nevesta, poetika epske formule. (26 April 2015) $<$ http://www.mirjanadetelic.com/docs/Urok\%20i\%20nevesta.pdf $>$.

Detelić, M. (2008). Formulativnost i usmena epska formula: atributi belo i junačko u srpskoj deseteračkoj epici. In: N. Ljubinković and S. Samardžija (eds.), Srpsko usmeno stvaralaštvo, zbornik radova, Belgrade: the Institute for Literature and Art, 119-145.

Jakobson, R. (1966). Lingvistika i poetika. Belgrade: Nolit.

Locke, G. N. W. (2011). The Serbian Epic Ballads. Belgrade: Tanesi.

Lord, A. B. (1990). Pevač priča. Belgrade: Idea. 
Meredith, O. (1866). Poems. (1 June 2015)

$<$ http://www.archive.org/stream/poems02lyttgoog\#page/n15/mode/1up >.

Noyes G. R. and L. Bacon (1913). Tsar Lazar and Tsaritsa Militsa. Heroic Ballads of Servia. (2 June 2015)

$<$ http://www.archive.org/stream/poems02lyttgoog\#page/n15/mode/1up $>$.

Suvajdžić, B. (2008). Od tradicije do usmenog „teksta“ - inicijalne formule u pesmama o hajducima i uskocima. In: N. Ljubinković and S. Samardžija (eds.), Srpsko usmeno stvaralaštvo, zbornik radova, Belgrade: The Institute for Literature and Art, 147-191. 